\title{
Some factors related to lipid profile in obese children at junior high schools in Manado
}

\author{
Anneke Helena Tangkilisan, Kartin Akune
}

\begin{abstract}
Background Factors related to lipid profile in obese children are calorie intake, fast food consuming habit, gender, physical activity, television (TV) watching, sleep duration, and visceral fat distribution. Objective To determine factors related to lipid profile in obese children at junior high school.

Methods We studied obese children aged $11-<15$ years from November 2004 to February 2005 at junior high school in Manado city. One hundred and seven junior high school children aged $11-<15$ years were enrolled in this study, excluding children with acute disease, having hypothyroidism, diabetes mellitus, chronic renal disease, liver disease, and using corticosteroid. The rsik factors considered were calorie intake, fast food consuming habit, gender, physical activity, TV watching, sleep duration, and waist circumference. The outcome measures were total cholesterol, LDL, HDL, non-HDL cholesterol, and triglyceride. Data was analyzed using $\mathrm{X}^{2}$, fisher exact test, Spearman's rho and multiple linear regression analysis with stepwise procedure.

Results The prevalence of increased total cholesterol was 28\%, LDL 44\%, triglyceride 16.8\%, low HDL cholesterol 6.5\%, and nonHDL was $23.3 \%$. There were statistically significant relationship between gender, calorie intake, fast food consuming habit, physical activity, TV watching, sleep duration, and total cholesterol. There were also statistically significant relationship between calorie intake, habit of consuming fast food, physical activity, TV watching, sleep duration, and LDL cholesterol. Fast food consuming habit and TV watching also had statistically significant relationship with HDL cholesterol. There were statistically significant relationship between calorie intake, physical activity, TV watching, and sleep duration with non-HDL cholesterol.

Conclusion Duration of TV watching, sleep duration, less physical activity and waist circumference $\geq 98$ percentile are correlated with hyperlipidemia in obese children. [Paediatr Indones 2007;47:166-171].
\end{abstract}

Keywords: Obese children, risk factors, lipid profile, television

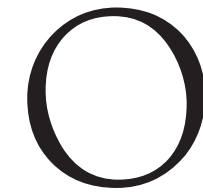
besity is a major nutritional problem. It is often found in developed countries and tends to be more apparent than that in the developing countries. Several years ago, cases of obesity in children started to appear in Indonesia, especially in the metropolitan. However, the data of obesity problem in children is still very limited. ${ }^{1}$

Obesity in children will persist until they reach adolescent period, only $4 \%$ will be normal in adult life, $60 \%$ become moderate obesity, and $84 \%$ become severe obesity. It may become risk factors of diseases such as hypertension, cardiovascular disease, diabetes mellitus, and hyperlipoproteinemia. ${ }^{2-4}$

The clinical cardiovascular manifestation in obesity is correlated with the changing of serum lipid profile. It began in childhood period and most of them were asymptomatic. ${ }^{5,6}$ The abnormality of fat and lipoprotein in obese patient generally are the increase of Low Density Lipoprotein (LDL) cholesterol, hypertriglyceridemia, and decrease of High Density Lipoprotein (HDL) cholesterol. ${ }^{7}$

From The Department of Child Health, Medical School, Sam Ratulangi University, Manado, Indonesia.

Reprint requests to: Anneke H. Tangkilisan, MD, Department of child Health, Medical School, Sam Ratulangi University, Prof R.D. Kandou Central General Hospital, Jl. Raya Tanawangko, Manado 95263, Indonesia. Telp. 62-431-821652;Fax 62-431-859091. 
Some factors related to lipid profile in obese children i.e. calorie intake ${ }^{8}, \operatorname{sex}^{9}, \operatorname{TV}_{\text {watch }}{ }^{10}$, sleep duration ${ }^{11}$, physical activity ${ }^{12}$, and visceral fat distribution. ${ }^{13}$ This study was aimed to determine factors related to lipid profile in obese children at junior high school.

\section{Methods}

This was an observational descriptive analytical correlation form using a cross sectional study design. This study took place at junior high schools in sub-districts of Wanea, Sario, and Malalayang, Manado, from November 2004 to February 2005. Samples were chosen by two stage cluster random sampling. In this study, there were 140 obese children aged $11-<15$ years old, but only 116 children gave back the questionnaire and got permission from parents. During the study period, there were only 107 children who met the study criteria and were able to be statistically analysed.

The inclusion criteria were junior high school children aged $11-<15$ years old whose parents agreed to enroll in this study. We excluded children with acute disease, having hypothyroidism, diabetes mellitus, chronic renal disease, liver disease, and those who were on corticosteroid treatment.

Obesity was defined as body mass index $\geq 95$ percentile based on CDC 2000 chart. Lipid profile was described as acceptable total cholesterol level $<170$ $\mathrm{mg} / \mathrm{dL}$, borderline 170-199 mg/dL, high $>200 \mathrm{mg} /$ $\mathrm{dL}$; acceptable LDL cholesterol level was $<110 \mathrm{mg} /$ $\mathrm{dL}$, borderline $110-129 \mathrm{mg} / \mathrm{dL}$, high $>130 \mathrm{mg} / \mathrm{dL} .^{14}$ Normal triglyceride level in male and female was $<138 \mathrm{mg} / \mathrm{dL}$ and high $>138 \mathrm{mg} / \mathrm{dL} .{ }^{15}$ Low HDL level was $<35 \mathrm{mg} / \mathrm{dL}$, normal was 35-84 mg/dL, and high HDL level was $>84 \mathrm{mg} / \mathrm{dL} .{ }^{16}$ Non-HDL cholesterol level $=$ total cholesterol - HDL cholesterol level with cut off point $=30 \mathrm{mg} / \mathrm{dL}+$ cut off point of LDL cholesterol level. ${ }^{17}$

Calorie intake was determined based on 24-hour food recall method. ${ }^{18}$ Fast food consuming habit was defined as the habit of children in consuming fast food such as hamburger, fried chicken, and pizza, with criteria as follows: frequently was once in a week, sometimes was once in $>1$ week- 3 months, and rarely was once in $\geq 3$ months. ${ }^{19}$

Physical activity was categorized as the kind of sports and activities done by the children. Physical ac- tivity was divided into: less, adequate and over. Less: no sports at all in a week or only mild activities (fishing, billiard, walking in 20 minutes, jogging) to less than 3 times a week in the last 3 weeks. Adequate: $3-5$ times in a week or moderate sports (karate, judo, walking $>20$ minutes, running 12 minutes $/ 1.5 \mathrm{~km}$ ) to heavy sports (badminton, basket ball, football, aerobics, table tennis, swimming, running 10 minutes $/ 1.5 \mathrm{~km}$ ) with a frequency $<3$ times in a week in the last 3 weeks with a duration of activities $>20$ minutes. Over: moderate to heavy sports with a frequency of 4-5 times a week in the last 3 weeks with a duration of $>20$ minutes. ${ }^{11}$

Duration of TV watching was defined as hours spent by children watching television. It was divided into less: $<2$ hours/day, moderate: $2-4$ hours/day, over: $>4$ hours/day. ${ }^{10}$ Duration of sleep was defined as the duration of sleep per day consisted of duration of night sleep and nap with criteria less: $<8$ hours, normal $8-10$ hours, more: $>10$ hours. ${ }^{20}$ Food recall method was applied using the domestic measurement units (plates, glasses, spoons) and based on meal noted since the last day (24-hour recall) within 3 consecutive days. Waist circumference for central obesity was $>98$ percentile according to the age and sex. The statistic was analyzed by multiple linear regressions with stepwise procedure for relationship of some factors to lipid profile.

\section{Results}

Boys tended to have higher cholesterol level compared to girls (35.1\% vs 20\%) (data not included). Obese children with high calorie intake had high total, LDL, and non-HDL cholesterol level (data not included). Obese children who frequently consumed fast food had high total and LDL cholesterol level (data not included). Obese children with less activity had high total, LDL-, and non-HDL cholesterol level (data not included). Obese children who watched TV $=4$ hours daily had high total, LDL-, non-HDL cholesterol and triglyceride level, but low HDL cholesterol level (data not included). Obese children who slept $>10$ hours daily had high total, LDL-, non-HDL, cholesterol and triglyceride level (data not included).

Duration of TV watch and sleep and waist circumference simultaneously had significant relationship with total and LDL cholesterol level (Table 2). 
Gender, waist circumference, duration of sleep and TV watch, habit of consuming fast food, physical activity and calorie intake did not have significant relationship with HDL cholesterol level (Table 3).

Significant relationship had been shown in the duration of TV watch with triglyceride level, as well as in the duration of TV watch, duration of sleep, and physical activity with non HDL cholesterol level (Table 4).

\section{Discussion}

Lipid profile in obese patients generally abnormal as shown by increased LDL cholesterol, hypertriglyceridemia, and decreased HDL cholesterol. ${ }^{7}$ Hyperlipidemia in obese children is one of the risk factors for the development of cardiovascular disease in the future. In this study, obese children with increased total cholesterol were $28 \%$, increased LDL cholesterol was $44 \%$, increased triglyceride was $16.8 \%$, decreased HDL cholesterol was $6.5 \%$, and increased non-HDL cholesterol $23.3 \%$. Hidayati et $a^{21}$ found that obese children with increased total cholesterol were $88.1 \%$, and with increased triglyceride was 10\%. The Bogalusa Heart Study found that gender and waist circumference were responsible for $7.7 \%$ of variant of non-HDL cholesterol. ${ }^{22}$

Increased calorie intake acts as synergetic factor in obesity that affects the lipid and serum lipoprotein level. ${ }^{19}$ This study's result indicated that there was a relationship between calorie intake and total cholesterol, LDL and non-HDL level in obese children.

Medical Research Council in London studied the relationship between the fast food consuming habits with cholesterol level. They reported that frequent fast food consumption would have a great effect on the prevalence of obesity and hyperlipidemia. ${ }^{23}$ Our study indicated that there were relationship between fast food consuming habit with total cholesterol, LDL, and HDL in obese children. Research in England (2003) indicated that $26 \%$ of obese children who consumed fast food had high LDL cholesterol. ${ }^{24}$

Android fat pattern in male which is defined as distribution of fat mostly in the upper body region, related to poor metabolic predictor, while gynoid fat pattern in female is relatively large fat in hip and thigh region and is related to lower risk of metabolism

Table 1. Subject's characteristics

\begin{tabular}{cllrrr}
\hline No & Subdistrict & Junior High School & Students & Obese & Subject \\
\hline \multirow{2}{*}{ 1. Wanea } & W & SMP Negeri 4 & 1035 & 37 & 27 \\
& & SMP Negeri 7 & 875 & 20 & 15 \\
& & SMP Kristen Diakonia & 40 & 1 & 1 \\
& & SMP Kristen Hati Kudus & 235 & 7 & 7 \\
2. Sario & SMP Kristen Zaitun & 78 & - & - \\
& & SMP Kristen El Shaddai & 33 & - & - \\
3. & Malalayang & SMP Kristen Advent II & 215 & 7 & 7 \\
& & SMP Negeri 8 & 1010 & 21 & 14 \\
& & SMP Khatolik Rafael & 539 & 30 & 23 \\
& & SMP Khatolik Theresia & 404 & 12 & 9 \\
& SMP Immanuel Bahu & 105 & 5 & 4 \\
\hline & T o t a I & 4569 & 140 & 107 \\
\hline
\end{tabular}

Table 2. Result of regression analysis of total \& LDL cholesterol

\begin{tabular}{lccc}
\hline \multicolumn{1}{c}{ Total } & Coefficients & $\mathrm{T}$ & $\mathrm{P}$ \\
\hline Constant & & & \\
TV viewing $\left(\mathrm{X}_{5}\right)$ & 51.41 & 2.12 & 0.36 \\
Duration of sleeping $\left(\mathrm{X}_{6}\right)$ & 10.85 & 4.46 & 0.000 \\
Waist circumference $\left(\mathrm{X}_{7}\right)$ & 5.74 & 2.85 & 0.005 \\
$\quad$ LDL & 33.72 & 2.35 & 0.02 \\
Constant & 10.12 & 0.46 & 0.64 \\
TV viewing $\left(\mathrm{X}_{5}\right)$ & 8.08 & 3.69 & 0.000 \\
Duration of sleeping $\left(\mathrm{X}_{6}\right)$ & 5.76 & 3.18 & 0.002 \\
Waist circumference $\left(\mathrm{X}_{7}\right)$ & 30.19 & 2.34 & 0.021 \\
\hline
\end{tabular}


Anneke Helena Tangkilisan et al: Factors related to lipid profile in obese children

Table 3. Regression analysis of HDL cholesterol

\begin{tabular}{lccc}
\hline & Coefficients & $\mathrm{T}$ & $\mathrm{P}$ \\
\hline Constant & 43.93 & 4.08 & 0.00 \\
Sex $\left(\mathrm{X}_{1}\right)$ & -2.95 & -1.86 & 0.067 \\
Waist circumference $\left(\mathrm{X}_{7}\right)$ & 2.10 & -0.50 & 0.62 \\
Duration of sleeping $\left(\mathrm{X}_{6}\right)$ & -0.014 & -0.23 & 0.81 \\
TV viewing $\left(\mathrm{X}_{5}\right)$ & 1.30 & 1.84 & 0.07 \\
Consume fast food $\left(\mathrm{X}_{3}\right)$ & -0.83 & -0.48 & 0.63 \\
Physical activity $\left(\mathrm{X}_{4}\right)$ & 0.80 & 0.46 & 0.65 \\
Calorie intake $\left(\mathrm{X}_{2}\right)$ & -0.017 & -0.32 & 0.75 \\
\hline
\end{tabular}

Table 4. Regression analysis of triglyceride \& non HDL cholesterol

\begin{tabular}{lccc}
\hline & Coefficients & $\mathrm{T}$ & $\mathrm{P}$ \\
\hline \multicolumn{1}{c}{ Triglyceride } & & & \\
Constant & 63.41 & 4.84 & 0.000 \\
TV viewing $\left(\mathrm{X}_{5}\right)$ & 8.92 & 2.89 & 0.005 \\
$\quad$ Non HDL & & & \\
Constant & 72.40 & 3.40 & 0.001 \\
TV viewing $\left(\mathrm{X}_{5}\right)$ & 8.50 & 3.49 & 0.001 \\
Duration of sleeping $\left(\mathrm{X}_{6}\right)$ & 5.00 & 2.51 & 0.01 \\
Physical activity $\left(\mathrm{X}_{7}\right)$ & -14.29 & -2.44 & 0.02 \\
\hline
\end{tabular}

disorder. ${ }^{16}$ Our study showed that there was a relationship between sex and total cholesterol. Lewis et $a^{25}$ found that female triglyceride transportation level was higher than that of male, it might be caused by high lipase lipoprotein activity in adipose tissue.

In general, obese individual is less active than individual with normal body weight. Low physical activity can increase lipoprotein. Physical activity is related to sport activity. Rhythmic exercise will burn calorie, stimulate metabolism of lipid, decrease body fat, and increase vascular health. ${ }^{9}$ Our study indicated that there was a relationship among physical activity with total cholesterol, LDL, and HDL level. This was similar to that reported by Craig et al $^{11}$ and Franklin et al. ${ }^{12}$

Long duration of watching television will decrease physical activity, decrease energy expenditure and lead to obesity and hypercholesterolemia. ${ }^{11}$ Our study showed that there were relationship between TV watch and total cholesterol, LDL, HDL, triglyceride and non-HDL cholesterol level. Wong et al26 found that watching TV $=2$ hours per day was correlated to the prevalence of hypercholesterolemia and watching TV $>4$ hours per day was the greatest predictor of hypercholesterolemia compared to other factors such as positive family history or non-genetic predictor like diet and nutritional status.

Excessive sleeping will lead to decrease physical activity and is resulted in obesity and hypercoles- terolemia. ${ }^{20}$ Obese children who slept more than 10 hours a day had high level of total cholesterol, LDL, triglyceride and non-HDL cholesterol. This finding was similar to that of their study ${ }^{27}$.

Fat distribution in obese children is related to lipid and serum lipoprotein level. Waist circumference can be used to predict the quantity of inner fat tissue which has direct relationship with fat-free mass. It is an important variable because it is related to intra-abdominal fat and metabolic complication, and lipid profile. ${ }^{28}$ This study indicated that there was no relationship between waist circumferences and total cholesterol, LDL, HDL, triglyceride, and non-HDL cholesterol level. Freedman et al ${ }^{29}$ found that body fat distribution on central region or abdomen was related to triglyceride, LDL, and HDL level. Bermingham et $a^{30}$ found the small result with the one reported in our study. Study on fat distribution among children and adolescents is not that simple because there are significant changes in waist circumference, skin-fold thickness, and lipoprotein level during growth and development. ${ }^{29}$ Furthermore, the amount of intra-abdominal fat, which may have primary role in adverse health outcomes, is small before adulthood. Children and adolescents, compared to adults, generally have relatively low quantity of intra-abdominal fat. It can be expected that only in more severe cases, the absolute amount 
Anneke Helena Tangkilisan et al: Factors related to lipid profile in obese children

of visceral adipose tissue will have an impact on lipid metabolism. ${ }^{6}$ However, the additional regression model showed that the duration of television watch and sleep, and waist circumference can be associated with total cholesterol and LDL cholesterol. We realized that cross sectional study design without control group was the limitation of our study.

\section{Acknowledgments}

We would like to thank all School Principles, and people who support and enroll in this study.

\section{References}

1. Rifai MA, Nonnji A, Erwidodo, editors. Gizi lebih pada anak dan masalahnya Risalah Widyakarya Pangan dan Gizi V; 1994 April 20-22; Jakarta. Jakarta: LIPI; 1994.

2. Bouchard C. Current understanding of the etiology of obesity: Genetic and non genetic factors. Am J Clin Nutr 1991;53:1561-5.

3. Dietz WH. Childhood and adolescent obesity. In: Walker WA, Watkins JB, editors. Nutrition in pediatrics. Boston: Little Brown; 1985. p. 60-80.

4. Kempe CH, Silver HK, O'Brien D, Fulginity VA. Obesity. In: Hay WW, editor. Current pediatric diagnosis \& treatment. 9th ed. Norwalk: Appleton \& Lange; 1991. p. 105-6.

5. Rubiana S, Prayoga AA, Sunarka N, Suandi IKG, Soetjiningsih. Gambaran klinis dan profil lipid serum pada anak obesitas di Sekolah Dasar Cipta Darma, Denpasar Bali. Proceedings of the 10th National Health Conggress; 1996 June 16-20; Bukit Tinggi, Indonesia. 1996.

6. Teixeire PJ, Sardinha LB, Going SB, Lahman TG. Total and regional fat and serum cardiovascular disease risk factor in lean and obese children and adolescents. Obesity Research 2001;9:432-8.

7. Einhorn PT, Rifkind BM, Bethesda. Cholesterol: myth vs. reality in pediatric practice. AJDC 1993;147:371-5.

8. Ranakusuma ABS. Lipoprotein dan aterogenesis. Naskah Lengkap Forum Ilmu Penyakit Dalam FKUI , Jakarta 1988: 70-8.

9. Heyward VH, Stolarczyk. Applied body composition assessment: human kinetics. Canada 1996:22-8.

10. Dietz WH JR, Gortmaker SL. Do we fatten our children at the television set? Obesity and television viewing in children and adolescent. Pediatrics 1985; 75:807-12.

11. Craig SB, Bandiri LG, Lichtenstein AH, Schoefer EJ, Dietz
WH. The impact of physical activity on lipids, lipoprotein and blood pressure in preadolescent girls. Pediatrics 1996;98:389-95.

12. Franklin WH, Allen HD, Fontana ME. Sport, physical activity and school problems. In: Emmanouilides GC, Riemenschneider TA, editors. Heart diseases in infant, children and adolescent. $5^{\text {th }}$ ed. Baltimore: William \& Wilkins Co; 1995. p. 643-9.

13. Wahidayat I, Matondang CS, Sastroasmoro S. Diagnosis fisik pada anak. Jakarta: FKUI, 1989. p. 220.

14. National Cholesterol Education Program (NCEP). Rationale for attention to cholesterol levels in children and adolescent. Report of the expert panel on blood cholesterol level in children and adolescents. Pediatrics 1992;88:S528-36.

15. Nicholson JF, Pesce MA. Reference ranger for laboratory tests. In: Behrman RE, Kliegman RM, Nelson We, Vaughan VC, editors. Nelson textbook of pediatrics. 16th ed. Philadelphia: WB Saunders; 1992. p. 1812-24

16. Franklin FA, Dashti N, Franklin CC. Evaluation and management of dyslipidemia in children. Endocr Met Clin North Am 1998;27:641-53.

17. National Cholesterol Education Program National Heart, Lung, and Blood Institute National Institute of Health. NIH Publication No.02-5215 2002:1-IX-7.

18. Kodyat B, Minarto, Raoef R, Sianturi G, Iryanis. Status konsumsi gizi di Indonesia: Analisis data survey konsumsi gizi tahun 1995. Gizi Indo 1996;21:40-50.

19. Fong H. Kegemaran makan makanan cepat saji: A matter of balance. In: Samsudin, Nassar SS, Syarif DR, editors. Masalah Gizi Ganda dan Tumbuh Kembang Anak. Jakarta: Naskah lengkap PKB Ilmu Kesehatan Anak FKUI, 1995. p. 114-9.

20. Widodo DP, editor. Perkembangan tidur pada anak dan kelainannya. Seminar Malam Klinik IDAI Jaya; 2000 August 27; Hilton International Hotel Jakarta: 2000.

21. Hidayati SN, Hadi H, Lesteriana W. The correlation between nutrient intakes with hyperlipidaemia on junior high school obesity students. Proceedings of the 2nd Asian Congress of Pediatric Nutrition; 2004 December 1-4; Sahid Jaya Hotel Jakarta: 2004. (abstract).

22. Srinivasan SR, Myers L, Berenson GS. Distribution and correlates of non high-density lipoprotein cholesterol in children: the Bogalusa Heart Study. Pediatrics 2002;110:1-4.

23. Medical Research Council. Fast food encourages eating and weight gain. October 2003. Available from: url: http:// www.mtc.ac.uk/index/public intrest/ public.

24. Waspadai kegemukan anak. Available from: url: http:// www.kompas.com/kompascetak/0309/27/iptek/587027.htm.

25. Lewis B, Mancini M, Mattock M, Chait A, Fraser TR. Plasma 
Anneke Helena Tangkilisan et al: Factors related to lipid profile in obese children

triglyceride and fatty acid metabolism in diabetes mellitus. Eur J Clin Invest 1972;2:445-53.

26. Wong ND, Hei TK, Qaqundah PY, Davidson DM, Bassin SL, Gold KV. Television viewing and pediatrics hypercholesterolemia. Pediatrics 1992;90:75-9.

27. Pieter R, Tangkilisan AH. Beberapa faktor yang berhubungan dengan kadar kolesterol total darah sebagai indikator uji saring hiperkolesterolemia pada anak sekolah usia 10-12 tahun di Kecamatan Wenang [thesis]. Program Pendidikan Dokter Spesialis-1 Ilmu Kesehatan Anak FK Unsrat Manado; 2004.
28. Tiengo A, Avogaro A. Cardiovascular disease. In: Bjorntorp P, editor. International textbook of obesity. New York: John Wiley and Sons; 2001. p. 364-77.

29. Freedman DS, Serdula MK, Srinivasan SR, Berenson GS. Relation of circumferences and skin-fold thickness to lipid and insulin concentration in children and adolescents: The Bogalusa Heart Study. Am J Clin Nutr 1999;69: 308-17.

30. Bermingham MA, Jones E, Steinbeck K, Brock K. Plasma cholesterol and other cardiac risk factor in adolescent girl. Arch Dis Child 1995;73:392-7. 